(c) American Dairy Science Association, 2007.

\title{
Effects of Feeding Fish Meal and n-3 Fatty Acids on Milk Yield and Metabolic Responses in Early Lactating Dairy Cows
}

\author{
A. R. Heravi Moussavi, ${ }^{*}$ R. O. Gilbert,† T. R. Overton,‡ D. E. Bauman,‡ and W. R. Butler ${ }^{1}$ \\ *Department of Animal Science, Ferdowsi University, Mashhad 91775-1163, Iran \\ †Department of Clinical Sciences, and \\ ‡Department of Animal Science, Cornell University, Ithaca, NY 14853
}

\section{ABSTRACT}

The study was designed to test the effects of feeding fish meal (FM) and specific n-3 fatty acids on milk yield and composition, dry matter intake, plasma concentrations of metabolic hormones and metabolites, and liver triglyceride accumulation in early lactating cows. From 5 to $50 \mathrm{~d}$ in milk (DIM), cows were fed diets that were isonitrogenous, isoenergetic, and isolipidic containing none (control), 1.25, 2.5, or 5\% menhaden FM or $2.3 \%$ Ca salts of fish oil fatty acids (CaFOFA). Milk yield (48.2, 49.8, 48.6, 53.5, and $52.2 \pm 1.0 \mathrm{~kg} / \mathrm{d}$, respectively) and dry matter intake $(22.7,22.8,23.0$, 23.8 , and $24.7 \pm 0.5 \mathrm{~kg} / \mathrm{d}$, respectively) differed among diets. Average daily plasma glucose concentration $(53.4,55.3,51.1,57.6$, and $57.3 \pm 1.3 \mathrm{mg} / \mathrm{dL}$, respectively) was also affected by diet, and plasma insulin concentration was increased by $5 \% \mathrm{FM}$ and $2.3 \% \mathrm{Ca}-$ FOFA. At 25 and 50 DIM, blood was collected before feeding and hourly for $11 \mathrm{~h}$ after feeding. Plasma glucose concentrations in cows during the day were similar among diets at 25 DIM, but differed at 50 DIM $(54.6,54.4,52.4,60.5$, and $58.3 \pm 1.4 \mathrm{mg} / \mathrm{dL}$ for 0 , $1.25,2.5$, and $5 \%$ FM or $2.3 \%$ CaFOFA, respectively). Plasma insulin was increased in cows fed 5\% FM and $2.3 \%$ CaFOFA at 25 DIM and was similar among diets at 50 DIM. Dietary treatments had no significant effect on milk composition, energy balance, or on daily plasma concentrations of nonesterified fatty acids, $\beta$ hydroxybutyrate, and urea. Plasma aspartate aminotransferase and hepatic triglyceride concentration in cows did not differ among diets at 21 DIM. Results from this experiment demonstrate that dietary supplementation with FM or n-3 polyunsaturated fatty acids in early lactating dairy cows significantly increased milk yield and DMI with no change in milk composition.

Key words: cow, fish meal, insulin, insulin-like growth factor-1

Received December 10, 2005.

Accepted August 14, 2006.

${ }^{1}$ Corresponding author: wrb2@cornell.edu

\section{INTRODUCTION}

During early lactation DMI lags behind the nutrient requirements for milk yield; consequently, lipids, proteins, and minerals are mobilized from body stores to support milk synthesis. Increasing ration nutrient density is one strategy to improve nutrient intake in early lactating cows. Fish meal (FM) is a source of high quality protein, and because it is less available for microbial degradation in the rumen, the quantity of undegraded protein reaching the small intestine is increased. Greater rumen escape of FM protein is known to increase efficiency of protein utilization in lactating cows (Broderick, 1992; Akayezu et al., 1997). Moreover, FM has an excellent profile of amino acids and is a good source for the 2 most limiting amino acids for milk synthesis, lysine and methionine (NRC, 2001). In addition, FM contains approximately $10 \%$ lipid including a significant amount of long-chain n-3 polyunsaturated fatty acids, eicosapentaenoic (EPA) and docosahexaenoic acid (DHA), and represents a source of energy for the early lactating cow.

Effects of feeding FM on milk yield are inconsistent (Santos et al., 1998). Although some reports observed increased milk yield by adding FM to the diet (Broderick, 1988; Atwal and Erfle, 1992; Carroll et al., 1994), others reported no benefit (Spain et al., 1995; AbuGhazaleh et al., 2001; Mattos et al., 2002). Reports on the effects of FM on milk composition are also inconsistent (Santos et al., 1998). In addition, effects on regulatory metabolic hormones and plasma metabolites of feeding FM or component polyunsaturated fatty acids in relation to milk yield have not been studied in early lactating cows. Fat supplements containing long-chain n-3 fatty acids are now commercially available for testing in dairy cows.

The objectives of the current study were to compare dietary supplementation with FM or specific longchain n-3 fatty acids from fish oil for effects on milk yield and composition, DMI, plasma metabolites, and metabolic hormones in early lactating dairy cows. 


\section{MATERIALS AND METHODS}

\section{Cows, Diets, and Sampling Procedures}

From 5 to 50 DIM, 31 multiparous cows were fed diets containing none (control; $\mathrm{n}=6), 1.25 \%(\mathrm{n}=6)$, $2.5 \%(\mathrm{n}=6)$, and 5\% ( $\mathrm{n}=6)$ menhaden FM (Sea-Lac, Omega Protein, Hammond, LA) or $2.3 \% \mathrm{Ca}$ salts of fish oil fatty acids (CaFOFA; EnerGII Repro; Virtus Nutrition, Fairlawn, $\mathrm{OH} ; \mathrm{n}=7$ ). Diets were formulated to be isonitrogenous, isoenergetic, and isolipidic (adjusted to 5\% lipid with Ca salts of palm oil fatty acids, EnerGII; Virtus Nutrition). Based on information provided from suppliers, the fatty acid composition of EPA, DHA, and total n-3 family were $12.6,7.8$, and $29.7 \mathrm{~g} / 100 \mathrm{~g}$ of fatty acids and $2.0,2.3$, and $5.3 \mathrm{~g} / 100$ $\mathrm{g}$ of fatty acids, for FM and CaFOFA, respectively. Fatty acid composition of the 2 commercial supplements is detailed in the companion paper (Heravi Moussavi et al., 2007). Both fat supplements were Ca salt formulations designed to render the fatty acids ruminally inert with regard to effects on microbial fermentation. The extent to which this technology protects unsaturated fatty acids from rumen biohydrogenation has not been extensively investigated, but the protection decreases as the degree of unsaturation increases (Wu et al., 1991). Variability in availability and degree of biohydrogenation of polyunsaturated fatty acids in the rumen is known to alter their flow for absorption in the lower gut (Shingfield et al., 2003); therefore, the amounts of these fatty acids reaching the lower gut are difficult to predict. We anticipated that 5\% FM and CaFOFA diets could provide similar amounts of bypass EPA and DHA for absorption. Diets were calculated to provide similar amounts of MP and $\mathrm{NE}_{\mathrm{L}}$ using the Cornell Net Carbohydrate and Protein System (Fox et al., 2004). Concentrates in the ration including FM and the fatty acid supplements were formulated into premixes for consistency of feeding across the entire study period. A forage mix common across diets was prepared and combined with each of the concentrate premixes in a weighing and mixing unit (American Calan, Inc., Northwood, $\mathrm{NH}$ ) and fed to cows in individual tie stalls once daily at $0930 \mathrm{~h}$ to allow 5 to $10 \%$ orts (as-fed basis). Orts were collected once daily and weighed. The TMR were sampled weekly throughout the experiment and DM content was determined by drying at $110^{\circ} \mathrm{C}$ for $18 \mathrm{~h}$. Samples of TMR and ingredients were collected weekly, composited monthly, and analyzed by wet chemistry procedures (DairyOne Laboratories, Ithaca, NY). Ingredient and nutrient composition of the diets are listed in Table 1 . Cows were milked 3 times per day at 0100, 0930, and $1700 \mathrm{~h}$ and yields were recorded automatically. Milk samples were collected from each milking on $1 \mathrm{~d}$ per wk and composited for analysis of fat, true protein, and lactose by midinfrared spectroscopy (DairyOne Laboratories, Ithaca, NY). Cows were weighed weekly after morning milking $(0930 \mathrm{~h})$ and BCS was recorded using a 5 -point scale $(1=$ thin to $5=$ fat; Edmonson et al., 1989). Net energy balance (EB) was calculated weekly from measurements of milk yield and composition, DMI, BW, and $\mathrm{NE}_{\mathrm{L}}$ value of the diet using the NRC (2001) equations. The Cornell University Institutional Animal Care and Use Committee approved all procedures involving experimental cows.

\section{Blood Collection and Analyses}

Blood samples were collected daily from 1 to 50 DIM via venipuncture from coccygeal vessels before the morning feeding to monitor plasma hormones and metabolites in this and the companion study (Heravi Moussavi et al., 2007). At d 25 and 50 (mid and end of dietary treatment), blood samples were collected before feeding and hourly for $11 \mathrm{~h}$ after morning feeding from indwelling jugular catheters inserted the previous day. Plasma from all blood samples was separated immediately after collection by centrifugation $(20 \mathrm{~min}$ at $1,000 \times \mathrm{g})$ and stored at $-20^{\circ} \mathrm{C}$ until analysis. Based on variances observed in a recent study (Butler et al., 2006), glucose, BHBA, plasma urea nitrogen (PUN), and NEFA were quantified every $2 \mathrm{~d}$, insulin was determined every $4 \mathrm{~d}$, and IGF-I was measured every $10 \mathrm{~d}$. Plasma aspartate aminotransferase (AST) was measured in samples collected at $\mathrm{d} 21$ by an automatic analyzer (Hitachi 917, Roche Co., Indianapolis, IN). Glucose, NEFA, and PUN also were quantified in plasma samples collected hourly on d 25 and 50 . Plasma IGF-I concentrations were quantified by RIA following acid-ethanol-acetone extraction (Enright et al., 1989) as previously described (Butler et al., 2004). Insulin concentrations were quantified by a doubleantibody RIA (Linco Research Inc., St Louis, MO) as described (Butler et al., 2003); with the exception that bovine insulin for iodination and standards was obtained from Elanco Animal Health (Greenfield, IN). Plasma metabolites were analyzed by enzymatic colorimetric assays using procedures modified from available kits (glucose: kit 510A and BHBA: kit 310-UV, Sigma-Aldrich Co.; NEFA, Wako Chemicals USA Inc., Dallas, TX) and validated in our laboratory. Analyses of glucose, NEFA, and BHBA were conducted in 96well microplates (Becton Dickinson and Co., Franklin Lakes, NJ) and read using a microplate reader (EL340, BioTek Instruments, Winooski, VT).

\section{Liver Biopsy and Triglyceride Analysis}

Liver tissue samples were collected on d 21 as previously described (Butler et al., 2003). After washing 
Table 1. Ingredient and chemical composition of the $\operatorname{diets}^{1}$ containing fish meal (FM) and Ca salts of fish oil fatty acids (CaFOFA)

\begin{tabular}{|c|c|c|c|c|c|}
\hline \multirow[b]{2}{*}{ Variable } & \multicolumn{5}{|c|}{ Diet } \\
\hline & Control & $\begin{array}{l}1.25 \% \\
\text { FM }\end{array}$ & $\begin{array}{l}2.5 \% \\
\text { FM }\end{array}$ & $\begin{array}{l}5.0 \% \\
\text { FM }\end{array}$ & $\begin{array}{l}2.3 \% \\
\text { CaFOFA }\end{array}$ \\
\hline \multicolumn{6}{|l|}{ Ingredient, $\%$ of DM } \\
\hline Alfalfa hay, chopped & 6.25 & 6.25 & 6.25 & 6.25 & 6.25 \\
\hline Mixed legume silage & 13.04 & 13.04 & 13.04 & 13.04 & 13.04 \\
\hline Corn silage & 32.61 & 32.61 & 32.61 & 32.61 & 32.61 \\
\hline \multicolumn{6}{|l|}{ Concentrate mixture } \\
\hline Corn, ground & 15.22 & 15.22 & 15.22 & 15.22 & 15.22 \\
\hline Citrus pulp & 6.52 & 6.52 & 6.52 & 6.52 & 6.52 \\
\hline Soybean meal & 10.87 & 10.87 & 10.87 & 10.87 & 10.87 \\
\hline Soybean hulls & 4.76 & 4.91 & 5.11 & 5.43 & 4.76 \\
\hline Soy plus & 2.17 & 1.63 & 1.09 & 0 & 2.17 \\
\hline Corn gluten meal & 2.39 & 1.80 & 1.20 & 0 & 2.39 \\
\hline Blood meal & 0.87 & 0.65 & 0.43 & 0 & 0.87 \\
\hline EnerGII $^{2}$ & 2.30 & 2.24 & 2.17 & 2.07 & 0 \\
\hline EnerGII Repro $^{2}$ & 0 & 0 & 0 & 0 & 2.30 \\
\hline Fish meal & 0 & 1.25 & 2.50 & 5.00 & 0 \\
\hline Mineral vitamin premix ${ }^{3}$ & 1.63 & 1.63 & 1.63 & 1.63 & 1.63 \\
\hline Sodium bicarbonate & 1.09 & 1.09 & 1.09 & 1.09 & 1.09 \\
\hline \multicolumn{6}{|l|}{ Chemical analysis, $\%$ of DM } \\
\hline $\mathrm{CP}$ & 17.99 & 17.80 & 18.16 & 18.46 & 17.78 \\
\hline $\mathrm{ADF}$ & 20.83 & 20.81 & 21.04 & 21.04 & 20.89 \\
\hline $\mathrm{NDF}$ & 31.25 & 31.67 & 31.27 & 31.82 & 31.40 \\
\hline $\mathrm{NFC}^{4}$ & 41.02 & 40.63 & 40.77 & 40.26 & 41.00 \\
\hline Ether extract & 4.76 & 4.85 & 5.10 & 5.00 & 4.73 \\
\hline Ash & 7.44 & 7.69 & 7.55 & 7.75 & 7.58 \\
\hline $\mathrm{Ca}$ & 1.11 & 1.04 & 1.13 & 1.13 & 1.10 \\
\hline $\mathrm{P}$ & 0.48 & 0.48 & 0.51 & 0.49 & 0.49 \\
\hline $\mathrm{Mg}$ & 0.36 & 0.34 & 0.36 & 0.37 & 0.33 \\
\hline $\mathrm{NE}_{\mathrm{L}}, \mathrm{Mcal} / \mathrm{kg}$ & 1.56 & 1.56 & 1.57 & 1.56 & 1.56 \\
\hline
\end{tabular}

${ }^{1}$ Values represent average of samples composited every $4 \mathrm{wk}$.

${ }^{2}$ Virtus Nutrition, Fairlawn, OH.

${ }^{3}$ The mix (DM basis) contained $20.0 \% \mathrm{Cl}, 13.0 \% \mathrm{Na}, 10.0 \% \mathrm{Ca}, 8.0 \% \mathrm{Mg}, 8.0 \% \mathrm{~S}, 1.0 \% \mathrm{~K}, 57 \mathrm{ppm}$ Co, 800 ppm Cu, 2,000 ppm Fe, 90 ppm I, 5,400 ppm Mn, 6,200 ppm Zn, 20 ppm Se, 550 IU/g vitamin A, 132 IU/ $\mathrm{g}$ vitamin $\mathrm{D}$, and $2.97 \mathrm{IU} / \mathrm{g}$ vitamin $\mathrm{E}$.

${ }^{4} \mathrm{NFC}=100-[(\mathrm{NDF}-$ neutral detergent insoluble $\mathrm{CP})+\mathrm{CP}+$ ash + ether extract $]$.

in saline and blotting dry, tissue was snap-frozen in liquid nitrogen, and stored at $-80^{\circ} \mathrm{C}$. Liver tissue $(\sim 150$ $\mathrm{mg}$ ) was homogenized with a polytron homogenizer in 2:1 chloroform:methanol for about $10 \mathrm{~s}$, total lipids were extracted, and triglyceride (TG) concentration was determined by a colorimetric Hantzsch condensation method (Butler et al., 2006).

\section{Western Ligand Blot of IGF-Binding Proteins}

Western ligand blotting as described by McGuire et al. (1995b) was performed on plasma samples collected at $\mathrm{d} 10$ and 21 to evaluate the pattern of IGF binding proteins (IGFBP). Plasma proteins were denatured in loading buffer (13.3\% SDS, $0.42 M$ Tris, $0.013 \%$ bromophenol blue, $\mathrm{pH} 6.5$ ) at $100^{\circ} \mathrm{C}$ for $3 \mathrm{~min}$ and separated using discontinuous SDS-PAGE at $175 \mathrm{~V}$ (double gel unit; Life Technologies Inc., Gaithersburg, MD). Proteins were transferred to a nitrocellulose membrane overnight at $10 \mathrm{~V}$ using a plate electrode apparatus (BioRad Laboratories Inc., Hercules, CA). Membranes were incubated for $16 \mathrm{~h}$ with ${ }^{125} \mathrm{I}$-IGF-I, washed, and placed on a phosphoimager screen for 48 h. Band intensities were quantified using a BioImaging Analyzer BAS 1000 (Fuji Photo Film Co. Ltd., Tokyo, Japan). Abundance of the IGFBP is expressed in arbitrary densitometry units. Binding proteins IGFBP-3 and IGFBP-2 were identified on the basis of molecular mass using the findings from another study on dairy cows that identified these proteins by immunoblot (McGuire et al., 1995b).

\section{Statistical Analyses}

Milk yield and composition, DMI, BW, BCS, and blood metabolites and hormones were analyzed by using a mixed model (PROC MIXED, SAS Inst. Inc., 
Cary, NC) for a completely randomized design with repeated measures using the following model:

$$
\mathrm{Y}_{\mathrm{ijk}}=\mu+\mathrm{T}_{\mathrm{i}}+\mathrm{A}_{(\mathrm{i}) \mathrm{j}}+\mathrm{D}_{\mathrm{k}}+(\mathrm{T} \times \mathrm{D})_{\mathrm{ik}}+\varepsilon_{\mathrm{ijk}},
$$

where $Y_{i j k}=$ dependent variable, $\mu=$ overall mean, $\mathrm{T}_{\mathrm{i}}=$ treatment effects, $\mathrm{A}_{(\mathrm{i}) \mathrm{j}}=$ random effects of animal within treatments, $D_{k}=$ effects of sampling day or time, $(\mathrm{T} \times \mathrm{D})_{\mathrm{ik}}=$ interaction effects of treatment and sampling day or time, and $\varepsilon_{\mathrm{ijk}}=$ residual error associated with the ijk observation.

For analyses of milk yield, DMI, BCS, BW, and NEFA, initial values available before starting the diets ( 1 to 4 DIM) were used as covariates. Overall effect of treatment was tested using cow within treatment as the error term. For all analyses, least squares means were calculated. Means were separated by TukeyKramer multiple range test. The relationship of daily milk yield and plasma IGF-I concentration on the same day was analyzed by linear regression (SAS Inst. Inc.).

Remaining data that were not repeated in time were analyzed by using a generalized linear model (PROC GLM; SAS Inst. Inc.) for a completely randomized design using the following model:

$$
\mathrm{Y}_{\mathrm{ij}}=\mu+\mathrm{T}_{\mathrm{i}}+\varepsilon_{\mathrm{ij}},
$$

where $Y_{i j}=$ dependent variable, $\mu=$ overall mean, $T_{i}=$ treatment effects, and $\varepsilon_{\mathrm{ij}}=$ residual error.

Means were separated by Duncan multiple range test. One cow in the 5\% FM group required treatment for ketosis between d 10 and 40 of lactation and was subsequently dropped from all analyses.

\section{RESULTS}

Milk yield was affected by diet and the cows fed $5 \%$ FM and $2.3 \%$ CaFOFA had greater $(P<0.01)$ production (Figure 1). Milk yield increased over time and no treatment $\times$ day interaction was detected $(P=0.35)$. Milk composition was similar among diets (Table 2), except that 5\% FM tended $(P<0.07)$ to increase milk protein. Both milk protein and fat percentages declined $(P<0.001)$ from wk 1 to 5 .

Dry matter intake was affected $(P<0.05)$ by diet, with the cows receiving 5\% FM and 2.3\% CaFOFA having the greatest intakes (Figure 1). The DMI increased with time and no treatment $\times$ day interaction was detected $(P=0.98)$. Intake of polyunsaturated fatty acids varied proportionately with amount of FM supplementation; the cows on the 5\% FM diet consumed 14.3, 8.8, and 33.6 g/d of EPA, DHA, and total n-3 fatty acids, respectively. Greater DMI for cows on the CaFOFA diet provided 11.8, 13.4, and $30.7 \mathrm{~g} / \mathrm{d}$ of

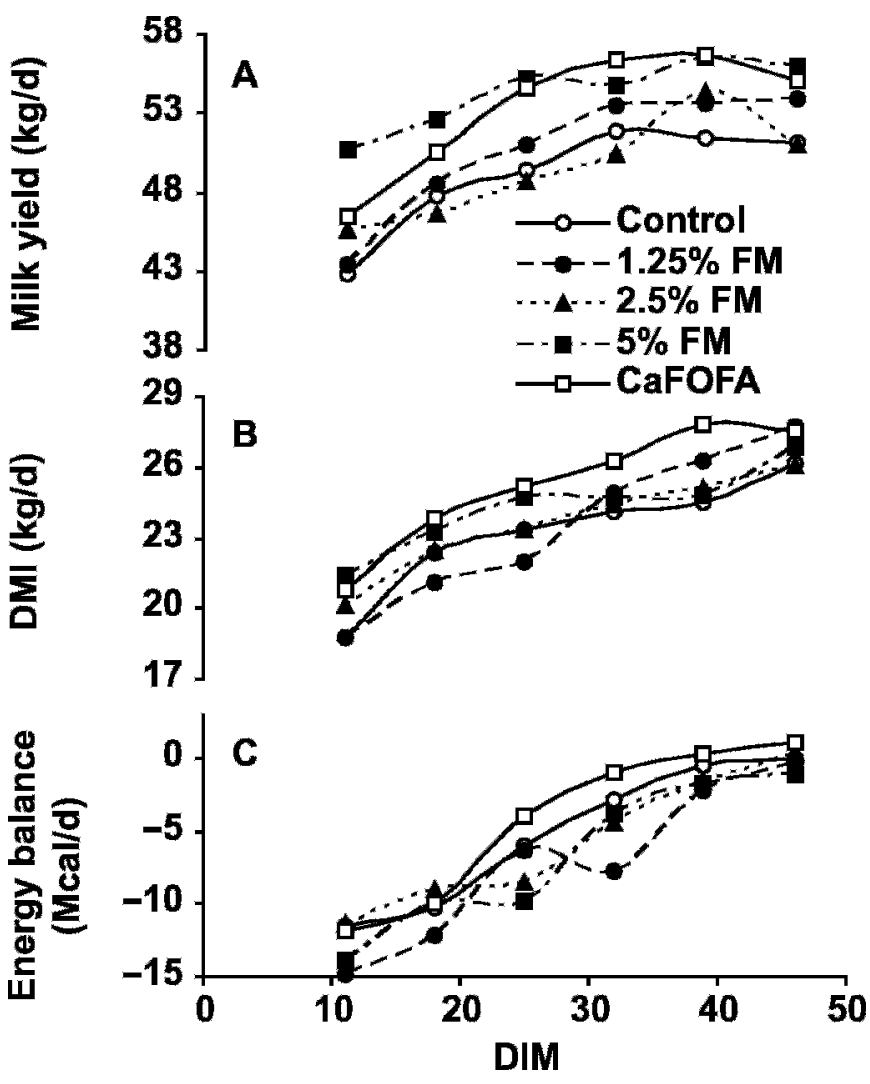

Figure 1. Effects of diets containing fish meal (FM) and $2.3 \% \mathrm{Ca}$ salts of fish oil fatty acids (CaFOFA) on weekly means for A) milk yield (pooled SE $=2.57 \mathrm{~kg} / \mathrm{d}$ ), B) DMI (pooled SE $=1.49 \mathrm{~kg} / \mathrm{d}$ ), and C) energy balance (pooled $\mathrm{SE}=2.31 \mathrm{Mcal} / \mathrm{d}$ ). Dietary treatment began on $\mathrm{d} 5$.

EPA, DHA, and total n-3 fatty acids, which was very similar to the $5 \% \mathrm{FM}$ diet. At calving, cows had a mean $( \pm \mathrm{SE}) \mathrm{BW}$ of $638 \pm 13 \mathrm{~kg}$ and a mean BCS of $3.05 \pm$ 0.07. Net EB was most negative during the first week after calving and mean weekly EB during feeding of treatment diets was similar among diets (Figure 1). Across all diets, energy intake exceeded energy requirement by wk 7 of study when EB averaged $3.8 \pm$ $2.3,3.1 \pm 2.3,0.3 \pm 2.3,1.5 \pm 2.5$, and $0.9 \pm 2.1 \mathrm{Mcal} /$ $\mathrm{d} \pm \mathrm{SE}$ for control, $1.25 \% \mathrm{FM}, 2.5 \% \mathrm{FM}, 5 \% \mathrm{FM}$, and CaFOFA diets, respectively. Average BCS and BW were similar among diets (Table 2) and BW declined $(P<0.001)$ during the study period.

Plasma glucose concentrations in daily blood samples were affected $(P<0.005)$ by the diets (Table 3$)$ and were greatest in cows fed 5\% FM and $2.3 \% \mathrm{CaFOFA}$. Plasma glucose increased with DIM $(P<0.001)$, but treatment $\times$ time was not significant. On d 25 (d 20 of treatment), diet did not affect mean plasma glucose concentrations before and during $11 \mathrm{~h}$ after feeding, but at $\mathrm{d} 50$, mean glucose concentrations during the 
Table 2. Milk composition, BCS, and BW in cows fed diets containing fish meal (FM) and Ca salts of fish oil fatty acids (CaFOFA) from 5 to 50 DIM

\begin{tabular}{|c|c|c|c|c|c|c|}
\hline \multirow[b]{2}{*}{ Variable } & \multicolumn{5}{|c|}{ Diet } & \multirow[b]{2}{*}{$\mathrm{SE}$} \\
\hline & Control & $\begin{array}{l}1.25 \% \\
\text { FM }\end{array}$ & $\begin{array}{l}2.5 \% \\
\text { FM }\end{array}$ & $\begin{array}{l}5 \% \\
\text { FM }\end{array}$ & $\begin{array}{l}2.3 \% \\
\text { CaFOFA }\end{array}$ & \\
\hline Milk fat, $\%$ & 3.8 & 3.9 & 4.0 & 3.8 & 3.7 & 0.2 \\
\hline Milk true protein, $\%$ & $2.8^{\mathrm{a}}$ & 2.8 & 2.9 & $3.0^{\mathrm{b}}$ & 2.9 & 0.1 \\
\hline Milk lactose, $\%$ & 4.6 & 4.7 & 4.6 & 4.7 & 4.7 & 0.1 \\
\hline $\mathrm{BCS}^{1}$ & 2.5 & 2.5 & 2.8 & 2.7 & 2.7 & 0.1 \\
\hline $\mathrm{BW},{ }^{2} \mathrm{~kg}$ & 584 & 580 & 579 & 573 & 588 & 8.1 \\
\hline
\end{tabular}

11-h sampling were affected $(P<0.01)$ by diet (Table 4). Effects of time and treatment $\times$ time were not significant at $\mathrm{d} 25$ and 50 .

Daily plasma insulin concentrations increased during the 50-d study (effect of time, $P<0.05$ ). Mean daily plasma insulin concentrations in cows differed $(P<$ 0.08 ) among diets (Table 3), with 5\% FM and 2.3\% CaFOFA having greater $(P<0.02)$ concentrations than control. During the frequent sampling periods after feeding, plasma insulin was affected $(P<0.05)$ by diet (Table 4) at d 25, with 5\% FM and 2.3\% CaFOFA having greater concentrations, but differences were not significant at d 50. For both days of frequent sampling, plasma insulin concentrations increased after feeding to maximum concentrations at $+7 \mathrm{~h}$.

Mean plasma concentrations of NEFA, BHBA, and PUN are in Table 3. Concentration of NEFA was similar $(P=0.11)$ among diets and decreased $(P<0.001)$ with increasing DIM. Plasma NEFA was highly variable from the beginning of the study (covariate: $P<$
$0.001)$ and remained greater $(P<0.05)$ in cows fed $5 \%$ FM compared with CaFOFA. Plasma BHBA in cows did not differ among diets, peaking at d $20(14.6 \pm 1.3$ $\mathrm{mg} / \mathrm{dL})$ before declining $(P<0.02)$ until the end of study. Diet did not affect PUN and increased $(P<$ $0.001)$ with DIM. Diet did not affect plasma concentrations of NEFA and PUN at d 25 and 50 during $11 \mathrm{~h}$ after feeding (Table 4).

Plasma IGF-I tended $(P=0.09)$ to be greater in the groups fed 5\% FM and 2.3\% CaFOFA compared with control (Table 3). Concentrations of IGF-I in all cows increased $(P<0.001)$ with time from d 5 to $45(40 \pm 4$ to $72 \pm 4 \mathrm{ng} / \mathrm{mL}$, respectively) and treatment $\times$ time was not significant $(P<0.65)$. Milk yield was strongly $(P<0.001)$ correlated $(\mathrm{r}=0.45)$ with plasma IGF-I concentration on the same day [n $=5$ samples/cow; milk $(\mathrm{kg})=0.14 \times$ IGF-I $(\mathrm{ng} / \mathrm{mL})+40.8]$. Plasma AST concentration and liver TG percentage in cows did not differ among diets at $21 \mathrm{~d}$ (Table 3 ). Across diets, the

Table 3. Plasma glucose, insulin, IGF-I, NEFA, BHBA, plasma urea N (PUN), plasma aspartate aminotransferase (AST), and liver triglyceride (TG) during the study period (5 to $50 \mathrm{DIM}$ ) in cows fed diets containing fish meal (FM) and Ca salts of fish oil fatty acids (CaFOFA)

\begin{tabular}{|c|c|c|c|c|c|c|}
\hline \multirow[b]{2}{*}{ Measurement } & \multicolumn{5}{|c|}{ Diet } & \multirow[b]{2}{*}{ SE } \\
\hline & Control & $\begin{array}{l}1.25 \% \\
\text { FM }\end{array}$ & $\begin{array}{l}2.5 \% \\
\text { FM }\end{array}$ & $\begin{array}{l}5 \% \\
\text { FM }\end{array}$ & $\begin{array}{l}2.3 \% \\
\text { CaFOFA }\end{array}$ & \\
\hline Glucose, $\mathrm{mg} / \mathrm{dL}$ & $53.4^{\mathrm{ab}}$ & $55.3^{\mathrm{b}, \mathrm{c}}$ & $51.1^{\mathrm{a}}$ & $57.6^{\mathrm{c}}$ & $57.3^{\mathrm{c}}$ & 1.3 \\
\hline Insulin, $\mathrm{ng} / \mathrm{mL}$ & $0.23^{\mathrm{d}}$ & 0.23 & 0.24 & $0.32^{\mathrm{e}}$ & $0.28^{\mathrm{e}}$ & 0.01 \\
\hline NEFA, $\mathrm{nmol} / \mathrm{mL}$ & 392.5 & 442.7 & 485.4 & 492.6 & 391.8 & 34.0 \\
\hline $\mathrm{BHBA}, \mathrm{mg} / \mathrm{dL}$ & 11.2 & 10.7 & 14.6 & 12.4 & 9.5 & 0.6 \\
\hline PUN, mg/dL & 14.9 & 14.5 & 15.0 & 13.6 & 15.1 & 0.5 \\
\hline IGF-I, ng/mL & $50.0^{x}$ & 46.9 & 63.7 & $64.1^{\mathrm{y}}$ & $67.2^{\mathrm{y}}$ & 3.9 \\
\hline $\mathrm{AST},{ }^{1} \mathrm{U} / \mathrm{L}$ & 117.2 & 139.6 & 109.6 & 115.3 & 103.7 & 13.3 \\
\hline Liver TG, $\%$ wet weight ${ }^{1}$ & 13.5 & 7.4 & 5.4 & 8.0 & 7.1 & 3.3 \\
\hline
\end{tabular}

${ }^{\mathrm{a}-\mathrm{c}}$ Means within a row that lack a common superscript letter $\operatorname{differ}(P<0.05)$.

d,e Means within a row that lack a common superscript letter differ $(P<0.02)$.

${ }^{\mathrm{x}, \mathrm{y}}$ Means within a row that lack a common superscript letter differ $(P=0.09)$.

${ }^{1}$ Determined from samples collected at 21 DIM. 
Table 4. Plasma concentrations ${ }^{1}$ of glucose, insulin, NEFA, and plasma urea N (PUN) on d 25 and 50 of lactation in cows fed diets containing fish meal (FM) and Ca salts of fish oil fatty acids (CaFOFA) from d 5

\begin{tabular}{|c|c|c|c|c|c|c|c|}
\hline \multirow[b]{2}{*}{ Measurement } & \multirow[b]{2}{*}{ DIM } & \multicolumn{5}{|c|}{ Diet } & \multirow[b]{2}{*}{ SE } \\
\hline & & Control & $\begin{array}{l}1.25 \% \\
\text { FM }\end{array}$ & $\begin{array}{l}2.5 \% \\
\text { FM }\end{array}$ & $\begin{array}{l}5 \% \\
\text { FM }\end{array}$ & $\begin{array}{l}2.3 \% \\
\text { CaFOFA }\end{array}$ & \\
\hline \multirow[t]{2}{*}{ Glucose, mg/dL } & 25 & 48.4 & 50.4 & 45.2 & 53.7 & 52.4 & 2.5 \\
\hline & 50 & $54.6^{\mathrm{ab}}$ & $54.4^{\mathrm{ab}}$ & $52.4^{\mathrm{a}}$ & $60.5^{\mathrm{c}}$ & $58.3^{\mathrm{bc}}$ & 1.4 \\
\hline \multirow[t]{2}{*}{ Insulin, ng/mL } & 25 & $0.30^{\mathrm{a}}$ & $0.31^{\mathrm{ab}}$ & $0.27^{\mathrm{a}}$ & $0.49^{c}$ & $0.45^{\mathrm{bc}}$ & 0.05 \\
\hline & 50 & 0.46 & 0.41 & 0.42 & 0.58 & 0.53 & 0.06 \\
\hline \multirow[t]{2}{*}{ NEFA, $\mathrm{nmol} / \mathrm{mL}$} & 25 & 324.2 & 370.2 & 400.4 & 307.3 & 241.9 & 51.4 \\
\hline & 50 & 185.3 & 209.4 & 261.1 & 203.4 & 234.5 & 22.6 \\
\hline \multirow[t]{2}{*}{ PUN, mg/dL } & 25 & 13.9 & 15.4 & 16.0 & 14.9 & 16.7 & 1.2 \\
\hline & 50 & 16.0 & 17.8 & 17.2 & 17.3 & 16.4 & 1.3 \\
\hline
\end{tabular}

${ }^{\mathrm{a}-\mathrm{c}}$ Means within a row that lack a common superscript letter differ $(P<0.05)$.

${ }^{1}$ Blood was collected before morning feeding and hourly for $11 \mathrm{~h}$ after feeding.

correlation $(\mathrm{r}=0.40)$ between AST and liver TG percentage was evident $(P<0.05)$.

Amount of IGFBP-2 in plasma, observed as a 34$\mathrm{kDa}$ band, was affected $(P<0.05)$ by $\operatorname{diets}(293,416$, 282,417 , and $312 \pm 32$ arbitrary densitometry units, respectively, for $0,1.25,2.5$, and $5 \% \mathrm{FM}$ and $2.3 \%$ CaFOFA) and IGFBP-2 decreased $(P<0.001)$ from d 10 to 21 (408 vs. $285 \pm 18$ arbitrary units, respectively). Amount of IGFBP-3 in plasma, observed as a 40 - to $44-\mathrm{kDa}$ doublet, differed $(P<0.01)$ among diets $(607$, $701,819,695$, and $462 \pm 60$ arbitrary units, respectively, for $0,1.25,2.5$, and $5 \% \mathrm{FM}$, and $2.3 \%$ CaFOFA). Amount of IGFBP-3 was increased $(P<0.001)$ from d 10 to 21 (596 \pm 31 to $718 \pm 31$ arbitrary units, respectively), coincident with increased $(P<0.05)$ plasma insulin concentrations $(0.14 \pm 0.03$ to $0.21 \pm 0.03 \mathrm{ng} /$ $\mathrm{mL}$, respectively).

\section{DISCUSSION}

Milk yield was increased by the dietary supplementation with 5\% FM and $2.3 \%$ CaFOFA. This result is similar to several previous reports that observed increased milk yield by adding FM (Broderick, 1988; Atwal and Erfle, 1992; Carroll et al., 1994) or fish oil (Keady et al., 2000) to the diet, whereas others have reported no increase in milk yield (Spain et al., 1995; Abu-Ghazaleh et al., 2001; Mattos et al., 2002). Forage-to-concentrate ratio, stage of lactation, solubility of FM protein, and diet composition are variables that may be related to the variation in milk response to FM supplementation (Abu-Ghazaleh et al., 2001). In a review of the literature, Santos et al. (1998) observed that milk yield was increased by FM in 8 of 32 studies, and cows producing more than $30 \mathrm{~kg}$ of milk per day, as in the current study, benefited more from FM supplementation than those producing less milk per day. Feeding FM has been reported to increase duodenal flow of nonammonia nonmicrobial $\mathrm{N}$ and also lysine and methionine (O'Mara et al., 1998). In the present study, the milk yield response to 5\% FM and $2.3 \%$ CaFOFA compared with the other diets seems to be accounted for by increased DMI in cows fed these 2 diets. It has been debated whether milk yield is driven by intake or intake is driven by milk yield. The 2 factors are clearly coordinated and on the basis of energyintake regulation theory, cows consume feed to meet energy needs, so intake is driven by milk yield (NRC, 2001).

Dry matter intake was affected by diet with cows fed 5\% FM and 2.3\% CaFOFA having the greatest DMI. The fact that adding FM to the diet did not decrease DMI was reported previously (Santos et al., 1998; Mattos et al., 2002). Donovan et al. (2000) showed DMI was similar to control when $1 \%$ fish oil was added to the diet, but was decreased by adding $3 \%$ fish oil. The decrease in DMI was thought to be because of decreased fiber digestion in the rumen or poor palatability. As the amount of FM used in the present study provided less than $0.5 \%$ fish oil (FM contains about $10 \%$ oil), this amount did not have any apparent negative effect on DMI and, in fact, DMI was increased in cows fed the 5\% FM diet. Although the early lactating cows were in negative EB, increased milk response to 5\% FM and 2.3\% CaFOFA was compensated for by increased DMI; negative EB was not different among treatments.

Plasma glucose concentrations were affected by diet and cows fed 5\% FM and 2.3\% CaFOFA had the greatest glucose concentrations. Fish oil increased ruminal propionate production (Keady and Mayne, 1999; Wachira et al., 2000; Fievez et al., 2003), and propionate is the single most important substrate for gluconeogenesis (Drackley et al., 2001). Fish oil apparently shifts patterns of rumen fermentation by decreasing methanogenesis that conserves energy and yields 
more propionate (Fievez et al., 2003). These effects seemed to be determined by the amount of the unique polyunsaturated fatty acids (i.e., EPA and DHA) present rather than simply by the total amount of unsaturated fatty acids. Greater abundance of unsaturated fatty acids, especially EPA and DHA, present in endometrial and liver tissue (Heravi Moussavi et al., 2007) demonstrated that FM and CaFOFA supplements enhanced availability of these fatty acids for absorption from the lower gut. In the present study, both 5\% FM and CaFOFA supplementation provided a source of EPA and DHA and increased blood glucose concentrations as an index of rumen propionate production. Increased plasma glucose concentrations indicate that glucose homeostasis was maintained at a greater level for support of increased milk yield. In addition, increased DMI in the 5\% FM and 2.3\% CaFOFA diets would be expected to increase amino acid absorption and availability for synthesis of milk protein and enhanced gluconeogenesis.

Consistent with the effects of diet on plasma glucose concentrations, circulating concentrations of insulin were greatest in cows receiving $5 \% \mathrm{FM}$ and $2.3 \% \mathrm{Ca}-$ FOFA. Cows fed these diets tended to have greater plasma IGF-I concentrations and milk yield also was increased in these cows. Recently, plasma IGF-I was shown to be positively correlated with milk yield response (Rose et al., 2005), and the current study confirms this relationship. Supplementation with FM or CaFOFA did not exert other general metabolic effects because neither plasma concentrations of NEFA, BHBA, PUN, and AST, nor liver TG concentrations differed among dietary treatments.

The IGFBP have several functions, including prolonging the half-life of IGF-I in circulation, transporting IGF-I from the vasculature to tissues, and localizing IGF-I to specific cell types and tissues (Cohick, 1998). In general, IGFBP-2 seems to inhibit IGF-I actions, but IGFBP-3 (which is the main carrier of IGFI in blood) has lesser binding affinity and potentiates IGF-I biologic effects (Jones and Clemmons, 1995). Results of the current study showed significant reduction of IGFBP-2 along with a significant increase in IGFBP3 from d 10 to 21 indicating greater IGF-I availability with increasing DIM. In the present study, plasma insulin concentrations also were increased during the same period and previous reports showed that IGFBP2 is inhibited by insulin (McGuire et al., 1995a; Mashek et al., 2001; Butler et al., 2003). Conversely, plasma IGFBP-3 was increased by insulin treatment in early postpartum cows (Butler et al., 2003). Increased milk yields in cows fed 5\% FM and $2.3 \% \mathrm{Ca}-$ FOFA were supported by the concurrent shifts in plasma IGFBP and more IGF-I along with increased DMI.

Milk fat percentage was similar among diets consistent with previous reports from feeding FM (Polan et al., 1997; Mattos et al., 2002). Other studies (Calsamiglia et al., 1995; Spain et al., 1995; Santos et al., 1998), however, reported significant reduction in milk fat percentage. Abu-Ghazaleh et al. (2001) showed that milk fat percentages and yields were decreased only when $100 \%$ of soybean meal was replaced with FM in the diet. Two conditions seem necessary for milk fat depression: presence of rumen substrate in the form of dietary unsaturated fatty acids and an altered rumen environment that leads to incomplete biohydrogenation (Bauman and Griinari, 2003) and production of various substrates and conjugated linoleic acid isomers (Bauman et al., 2003). Diet-induced milk fat depression in dairy cows results from a coordinated reduction in mRNA abundance for multiple genes associated with mammary lipid synthesis in association with appearance of trans-10, cis-12 conjugated linoleic acid in milk fat (Peterson et al., 2003). It was suggested that fish oils are more likely to cause milk fat depression when they are included in diets containing large amounts of fats (Calsamiglia et al., 1995) or fed to cows yielding $<30 \mathrm{~kg}$ of milk/d (Santos et al., 1998).

Milk protein percentage was similar among diets consistent with other reports (Polan et al., 1997; Mattos et al., 2002), although milk protein production tended to be greater in cows fed the 5\% FM diet. Milk protein percentage was increased when FM completely replaced soybean meal in the diet (Abu-Ghazaleh et al., 2001) or provided $11 \%$ of dietary CP (Akayezu et al., 1997). Milk protein percentages were not consistently affected by FM supplementation, but cows yielding $<30 \mathrm{~kg}$ of milk/d tended to decrease milk protein percentages when fed FM (Santos et al., 1998). On the other hand, cows fed diets of alfalfa silage showed greater increases in milk protein percentage when fed FM than did cows fed other forages, perhaps because such diets generally provide less flow of essential fatty acids to the duodenum (Broderick, 1992; Santos et al., 1998). Diets in the present study were formulated to contain similar amounts of MP. Cows with greater DMI would have a greater supply of MP, but milk protein concentrations remained similar among diets.

In conclusion, results of this study demonstrate that feeding FM and CaFOFA increased milk yield in early lactating dairy cows. Increased milk yield was related to increased DMI and greater plasma glucose concentrations that likely reflect the ruminal effects of the polyunsaturated fatty acids, EPA and DHA. Adding $5 \% \mathrm{FM}$ or $2.3 \%$ CaFOFA to the diet increased circulating concentrations of insulin and IGF-I, but plasma 
concentrations of NEFA, BHBA, PUN, and AST as well as liver TG were similar among dietary treatments.

\section{ACKNOWLEDGMENTS}

Fish meal used in this study was generously donated by Omega Protein (Hammond, LA) and the EnerG II and EnerG II Repro were generously provided by Virtus Nutrition (Fairlawn, $\mathrm{OH}$ ). These companies also provided financial support for the study. R. W. Canfield and Cargill Animal Nutrition (Liverpool, NY) provided ingredients and expertise in blending $\mathrm{FM}$ and $\mathrm{Ca}$ FOFA supplement premixes. The authors thank the staff of the Teaching and Research Center of Cornell University for their assistance in this experiment and excellent care of the cows. AliReza Heravi Moussavi was partially supported by the Iranian Ministry of Science, Research, and Technology for living expenses during his work at Cornell University.

\section{REFERENCES}

Abu-Ghazaleh, A. A., D. J. Schingoethe, and A. R. Hippen. 2001. Blood amino acids and milk composition from cows fed soybean meal, fish meal, or both. J. Dairy Sci. 84:1174-1181.

Akayezu, J. M., W. P. Hansen, D. E. Otterby, B. A. Crooker, and G. D. Marx. 1997. Yield response of lactating Holstein dairy cows to dietary fish meal and bone meal. J. Dairy Sci. 80:2950-2963.

Atwal, A. S., and J. D. Erfle. 1992. Effects of feeding fish meal to cows on digestibility, milk production, and milk composition. J. Dairy Sci. 75:502-507.

Bauman, D. E., B. A. Corl, and D. G. Peterson. 2003. The biology of conjugated linoleic acids in ruminants. Pages 146-173 in Advances in Conjugated Linoleic Acid Research. Vol. II. J. L. Sébédio, W. W. Christie, and R. Adlof, ed. AOCS Press, Champaign, IL.

Bauman, D. E., and J. M. Griinari. 2003. Nutritional regulation of milk fat synthesis. Annu. Rev. Nutr. 23:203-227.

Broderick, G. A. 1988. Fish meal vs solvent soybean meal for lactating cows fed alfalfa silage as sole forage. Page 59 in US Dairy Forage Research Center Summaries. Madison, WI.

Broderick, G. L. 1992. Relative value of fish meal versus soybean meal for lactating dairy cows fed alfalfa silage as sole forage. J. Dairy Sci. 75:174-183.

Butler, S. T., A. L. Marr, S. H. Pelton, R. P. Radcliff, M. C. Lucy, and W. R. Butler. 2003. Insulin restores GH responsiveness during lactation-induced negative energy balance in dairy cattle: Effects on expression of IGF-I and GH receptor 1A. J. Endocrinol. 176:205-217.

Butler, S. T., S. H. Pelton, and W. R. Butler. 2004. Insulin increases $17 \beta$-estradiol production by the dominant follicle of the first postpartum follicle wave in dairy cows. Reproduction 127:537-545.

Butler, S. T., S. H. Pelton, and W. R. Butler. 2006. Energy balance, metabolic status, and the first postpartum ovarian follicle wave in cows administered propylene glycol. J. Dairy Sci. 89:29382951.

Calsamiglia, S., G. Caja, M. D. Stern, and B. A. Crooker. 1995. Effects of ruminal versus duodenal dosing of fish meal on ruminal fermentation and milk composition. J. Dairy Sci. 78:19992007.

Carroll, D. J., F. R. Hossain, and M. R. Keller. 1994. Effect of supplemental fish meal on the lactation and reproductive performance of dairy cows. J. Dairy Sci. 77:3058-3072.

Cohick, W. S. 1998. Role of the insulin-like growth factors and their binding proteins in lactation. J. Dairy Sci. 81:1769-1777.
Donovan, D. C., D. J. Schingoethe, R. J. Baer, J. Ryali, A. R. Hippen, and S. T. Franklin. 2000. Influence of dietary fish oil on conjugated linoleic acid and other fatty acids in milk fat from lactating dairy cows. J. Dairy Sci. 83:2620-2628.

Drackley, J. K., T. R. Overton, and G. N. Douglas. 2001. Adaptation of glucose and long-chain fatty acid metabolism in liver of dairy cows during the periparturient period. J. Dairy Sci. 84(E. Suppl.):E100-E112.

Edmonson, A. J., I. J. Lean, L. D. Weaver, T. Farver, and G. Webster. 1989. A body condition scoring chart for Holstein dairy cows. J. Dairy Sci. 72:68-78.

Enright, W. J., L. T. Chapin, W. M. Moseley, S. A. Zinn, M. B. Kamdar, L. F. Krabill, and H. A. Tucker. 1989. Effects of infusions of various doses of bovine growth hormone-releasing factor on blood hormones and metabolites in lactating Holstein cows. J. Endocrinol. 122:671-679.

Fievez, V., F. Dohme, M. Danneels, K. Raes, and D. Demeyer. 2003. Fish oils as potent rumen methane inhibitors and associated effects on rumen fermentation in vitro and in vivo. Anim. Feed Sci. Technol. 104:41-58.

Fox, D. G., L. O. Tedeschi, T. P. Tylutki, J. B. Russell, M. E. Van Amburgh, L. E. Chase, A. N. Pell, and T. R. Overton. 2004. The Cornell Net Carbohydrate and Protein System model for evaluating herd nutrition and nutrient excretion. Anim. Feed Sci. Technol. 112:29-78.

Heravi Moussavi, A. R., R. O. Gilbert, T. R. Overton, D. E. Bauman, and W. R. Butler. 2007. Effects of feeding fish meal and n-3 fatty acids on ovarian and uterine responses in early lactating dairy cows. J. Dairy Sci. 90:145-154.

Jones, J. I., and D. R. Clemmons. 1995. Insulin-like growth factors and their binding proteins: Biological actions. Endocr. Rev. 16:3-34.

Keady, T. W. J., and C. S. Mayne. 1999. The effects of level of fish oil inclusion in the diet on rumen digestion and fermentation parameters in cattle offered grass silage based diets. Anim. Feed Sci. Technol. 81:57-68.

Keady, T. W. J., C. S. Mayne, and D. A. Fitzpatrick. 2000. Effects of supplementation of dairy cattle with fish oil on silage intake, milk yield and milk composition. J. Dairy Res. 67:137-153.

Mashek, D. G., K. L. Ingvartsen, J. B. Andersen, M. Vestergaard, and T. Larsen. 2001. Effects of a four-day hyperinsulinemiceuglycemic clamp in early and mid-lactation dairy cows on plasma concentrations of metabolites, hormones, and binding proteins. Domest. Anim. Endocrinol. 21:169-185.

Mattos, R., C. R. Staples, J. Williams, A. Amorocho, M. A. McGuire, and W. W. Thatcher. 2002. Uterine, ovarian, and production responses of lactating dairy cows to increasing dietary concentrations of menhaden fish meal. J. Dairy Sci. 85:755-764.

McGuire, M. A., D. E. Bauman, D. A. Dwyer, and W. S. Cohick. 1995a. Nutritional modulation of the somatotropin/insulin-like growth factor system: Response to feed deprivation in lactating cows. J. Nutr. 125:493-502.

McGuire, M. A., D. A. Dwyer, R. J. Harrell, and D. E. Bauman. 1995b. Insulin regulates circulating insulin-like growth factors and some of their binding proteins in lactating cows. Am. J. Physiol. 269:E723-E730.

National Research Council. Nutrient Requirements of Dairy Cattle. 7th rev. ed. 2001. National Academy Press, Washington, DC.

O'Mara, F. P., J. J. Murphy, and M. Rath. 1998. Effect of amount of dietary supplement and source of protein on milk production, ruminal fermentation, and nutrient flows in dairy cows. J. Dairy Sci. 81:2430-2439.

Peterson, D. G., E. A. Matitashvili, and D. E. Bauman. 2003. Dietinduced milk fat depression in dairy cows results in increased trans-10, cis-12 CLA in milk fat and coordinate suppression of mRNA abundance for mammary enzymes involved in milk fat synthesis. J. Nutr. 133:3098-3102.

Polan, C. E., G. Cozzi, P. Berzaghi, and I. Andrighetto. 1997. A blend of animal and cereal protein or fish meal as partial replacement for soybean meal in the diets of lactating Holstein cows. J. Dairy Sci. 80:160-166. 
Rose, M. T., T. E. C. Weekes, and P. Rowlinson. 2005. Correlation of blood and milk components with the milk yield response to bovine somatotropin in dairy cows. Domest. Anim. Endocrinol. 28:296-307.

Santos, F. A., J. E. Santos, C. B. Theurer, and J. T. Huber. 1998. Effects of rumen-undegradable protein on dairy cow performance: A 12-year literature review. J. Dairy Sci. 81:3182-3213.

Shingfield, K. J., S. Ahvenjarvi, V. Toivonen, A. Arola, K. V. V. Nurmela, P. Huhtanen, and J. M. Griinari. 2003. Effect of dietary fish oil on biohydrogenation of fatty acids and milk fatty acid content in cows. Anim. Sci. 77:165-179.
Spain, J. N., C. E. Polan, and B. A. Watkins. 1995. Evaluating effects of fish meal on milk fat yield of dairy cows. J. Dairy Sci. 78:1142-1153.

Wachira, A. M., L. A. Sinclair, R. G. Wilkinson, K. Hallett, M. Enser, and J. D. Wood. 2000. Rumen biohydrogenation of n-3 polyunsaturated fatty acids and their effects on microbial efficiency and nutrient digestibility in sheep. J. Agric. Sci. (Camb.) 135:419428.

Wu, Z., O. A. Ohajuruka, and D. L. Palmquist. 1991. Ruminal synthesis, biohydrogenation and digestibility of fatty acids by dairy cows. J. Dairy Sci. 74:3025-3034. 